\title{
Evaluation of Synergetic Antibacterial Effect of Gaseous Ozone and Ozonated Water against Enterococcus Faecalis in Human Root Canals
}

\author{
Banu Uygun Can ${ }^{1}$, Gizem Özbay², Hatice Altundal', Parla Meva Durmazpinar ${ }^{3}$, Burak Kitiki², Sertaç \\ Peker $^{2}$, Tanju Kadir ${ }^{1}$ and Betül Kargul ${ }^{4}$
}

${ }^{1}$ Department of Microbiology, Marmara University, Turkey

${ }^{2}$ Private Practice, Istanbul, Turkey

${ }^{3}$ Department of Endodontics, Izmir Demokrasi University, Turkey

${ }^{4}$ Department of Pediatric Dentistry, Marmara University, Turkey

*Corresponding author: Dr. Parla Meva Durmazpinar, Department of Endodontics, Izmir Demokrasi University, Üçkuyular Mahallesi, Gürsel Aksel Bulvari, No: 1435140 Karabağlar/izmir, Turkey, Tel: +90-533-211-11-48, Fax: +90-232-260-1004

\begin{abstract}
Background: Elimination of the microorganisms in root canals is one of the most important stages for a successful endodontic treatment. Several techniques and agents have been tested to find an alternative option to sodium hypochloride for effective root canal disinfection. The aim of this in vitro study was to evaluate the antimicrobial efficacy of gaseous ozone and ozonated water in order to establish their potential as endodontic root canal disinfectant.

Methods: Eighty teeth with single canal were prepared and inoculated with Enterococcus faecalis suspension and incubated for a week. The contaminated root canals were exposed to irrigating solutions including gaseous ozone $\left(44 \mathrm{\mu g} \mathrm{ml}^{-1}\right)$ with ozonated water $\left(5 \mu \mathrm{g} \mathrm{ml}^{-1}\right), 5.25 \%$ sodium hypochlorite, $2 \%$ chlorhexidine for $3 \mathrm{~min}$. Samples from the root canals were collected by paper points, before and after irrigation. The bacterial count was analyzed by serial decimal dilutions and the percentage of surviving microorganisms was statistically assessed.

Results: There was a significant reduction in the bacterial count after all treatments $(P<0.001)$ while having greater antimicrobial reduction was observed on samples of $\mathrm{NaOCl}$ irrigation. There was no significant difference between gaseous ozone and gaseous ozone + ozonated water groups.

Conclusion: Under limitations of this study, it could be concluded that the gaseous ozone, as an irrigant agent, significantly reduced the number of $E$. faecalis in root canals but was not able to eliminate it. However, ozonated water was insufficient to increase the antibacterial effectiveness of gaseous ozone.
\end{abstract}

\section{Keywords}

Chlorhexidine, Enterococcus faecalis, Gaseous ozone, Ozonated water

\section{Introduction}

An approving outcome of the endodontic treatment of teeth with apical periodontitis depends on effective control of the root canal infection [1,2]. Chemomechanical preparation root canals can reduce the number of microorganisms but not entirely get rid of them [3]. Instead of strict anaerobes, some facultative anaerobic bacteria, especially $E$. faecalis have been shown to be associated with failed root canal treatment $[4,5]$. Inadequate aseptic control and instrumentation of the root canals, leaking temporary or permanent cavity restorations are the main factors that may be critically important in post-treatment endodontic disease. Microbiological findings from filled root canals with periapical disease have shown a high proportion of enterococci, ranging from $24 \%$ to $77 \%$ [6]. E. faecalis has ability to grow in high salt concentrations, a wide temperature range, tolerance a broad $\mathrm{pH}$ range, as well as growth or persist in the presence of intracanal medicaments $[4,7]$. Thus, effective disinfecting processes and antimicrobial irrigants to remove $E$. faecalis are necessary for successful treatment of the infected root canals, especially 
those with persistent apical periodontitis [8].

Sodium hypochlorite $(\mathrm{NaOCl})$ has been widely used as an irrigant since its introduction in Endodontics by Walker in 1936, however it has cytotoxic and neurotoxic effects when infused into the periapical tissues [9]. It has been notified that the antibacterial and tissue-dissolution property of $\mathrm{NaOCl}$ increases with its concentration, but this is also accompanied by an increase in its toxicity [10]. To avoid the potential side effects of $\mathrm{NaOCl}$, there is an interest in developing new disinfecting agents and methods.

Another antimicrobial agent is Chlorhexidine gluconate $(\mathrm{CHX})$ which has been recommended for the root canal irrigation [11]. $\mathrm{CHX}$ is a cationic molecule, which has a wide range of antimicrobial activity [12]. On the other hand, $\mathrm{CHX}$ may cause mucosal desquamation and a high cytotoxic effect on epithelial cells [13]. Therefore, many recent studies have focused on an alternative disinfectant irrigant with high effective as well as relative lack of toxicity against sound apical tissue $[14,15]$.

Ozone is a natural allotrope of oxygen found in upper layer of atmosphere protecting living organisms on earth from Ultraviolet (U.V) radiation. It is a powerful oxidizing agent and currently being discussed as a possible alternative antiseptic in dentistry due to its high antimicrobial effect without the development of drug resistance [16]. Ozone damages the bacterial cell membranes by ozonolysis and oxidates intracellular proteins leading to loss of organelle function [17]. This action is selective to microbial cells and thus does not affect human body cell. Ozone is a good antioxidative and very effective in antibiotic resistant strains with accelerated efficiency in acidic pH environment [18]. It is administered on patients for therapeutic purposes in various forms like gaseous ozone, as an aqueous solution, oil or as ozonated water $[16,19]$. Kist, et al. suggested that ozone gas might be a possible alternative disinfection agent within the root canal treatment of apical periodontitis based on the results of a clinical trial [20]. Furthermore, It has been shown that ozonated water (up to $20 \mathrm{gm} \mathrm{L}^{1}$ ) is non-toxic against oral cells in vitro and the ozone gas $\left(4 \mathrm{gm}^{3}\right)$ is slightly less toxic than $2.5 \% \mathrm{NaOCl}$ [21]. In the light of this information, the aim of this in vitro study was to evaluate antimicrobial efficiency of gaseous ozone with aditional use of ozonated water against E. faecalis in root canals and compare with traditional endodontic irrigants such as $\mathrm{NaOCl}$ and $\mathrm{CHX}$. The null hypothesis of the present study was that there would be no difference in elimination of $E$. faecalis among gaseous ozone, gaseous ozone + ozonated water and $2.5 \% \mathrm{NaOCl}$ groups.

\section{Methods}

\section{Tooth preparation}

The study consisted of eighty single-rooted human permanent teeth which extracted because of periodon- tal disease or extensive carious lesions. The investigation was obtained by the Ethics Committee of the Health Sciences Institute of University of Marmara, Turkey (No.153/2015). The external root surface of the teeth was cleaned with curettes to remove calculus and periodontal soft tissues. A \#10 K-type file (K-Files, Mani Inc., Utsunomiya, Japan) was used to confirm patency of the root canal and to establish a clinical working length 1 $\mathrm{mm}$ short of the apical foramen. Root canal preparation commenced with Gates Glidden Burs 4-3-2 (Dentsply Maillefer, Ballaigues, Switzerland) in a crown-down mode [22]. Biomechanical root-canal preparation was done by step-back technique up to a size $70 \mathrm{~K}$-File (taper 0.02) (Dentsply Maillefer, Ballaigues, Switzerland) [23]. Canals were irrigated with $1 \mathrm{ml}$ of $2.5 \% \mathrm{NaOCl}$ (Wizard, Rehber Chemistry, Istanbul, Turkey) between each instrument. After the mechanic preparation of the root canals, they were filled with $1 \mathrm{ml}$ 15\% Ethylenediaminetetraacetic acid (EDTA) for $1 \mathrm{~min}$ followed by a final rinse with $1 \mathrm{~mL} 2.5 \% \mathrm{NaOCl}$ and $1 \mathrm{ml}$ saline solution for smear layer removal [24]. Then the teeth were decoronated to a constant root canal length of $16 \mathrm{~mm}$ with a rotary diamond saw (BUEHLER, Isomet low speed saw, IL) at $700 \mathrm{rpm}$ under water-cooling [25]. Apical foramina were sealed with a restorative material (Z100; 3M ESPE, Seefeld, Germany) and outer surfaces of the roots were covered with two layers of nail varnish. Teeth were embedded into epoxy resin (Clássico, Artigos Odontológi$\cos$ S/A, São Paulo, SP, Brazil) to prevent bacterial leakage. All samples were sterilized by autoclaving $\left(120{ }^{\circ} \mathrm{C}\right.$ for $30 \mathrm{~min})$.

\section{Tested organism}

A reference strain of Gram-positive facultative anaerobic coccus (E. faecalis ATCC 29212) obtained from our laboratory stock collection was used. Bacteria were plated onto Brain-heart infusion (BHI) agar (SigmaAldrich, Co., St. Louis, USA) and incubated aerobically at $37^{\circ} \mathrm{C}$ for 24 hours, then suspended in BHI broth (SigmaAldrich St., Louis, USA) and the optical density was adjusted to optical turbidity of McFarland 0.5 to obtain approximately $1 \times 10^{8}$ colony forming units (CFU/ml).

The experimental groups were inoculated with $E$. faecalis suspension $\left(1 \times 10^{8} \mathrm{CFU} / \mathrm{ml}\right)$, using sterile $2 \mathrm{ml}$ tuberculin syringes of sufficient volume to fill the root canal. Then the samples were incubated for 7 days aerobically at $37^{\circ} \mathrm{C}$. The inoculum was renewed every 3 days, always using 24 hours pure culture prepared and adjusted to the same turbidity of the first suspension.

\section{Experimental design}

After incubation of the samples, they were randomly divided into five experimental groups ( $n: 15)$;

Group 1, $\mathrm{NaOCl}$ group: The root canals were irrigated with $5 \mathrm{ml} 5.25 \% \mathrm{NaOCl}$ (Sultan Chemists, Inc, Englewood. NJ, USA) for 3 min using 30-gauge needle (NaviTip FX; Ultradent Products Inc, South. Jordan, UT), 
Table 1: Counts of $E$. faecalis CFUs before and after disinfection protocols.

\begin{tabular}{|l|l|l|l|l|l|l|l|}
\hline & \multicolumn{3}{l}{ Before treatment } & \multicolumn{2}{l|}{ After treatment } & \multicolumn{1}{l|}{ p } \\
\cline { 2 - 8 } & Mean & Median & Range & Mean & Median & Range & $0.001^{*}$ \\
\hline $5.25 \% \mathrm{NaOCl}$ & $1.34 \times 10^{8}$ & $1 \times 10^{8}$ & $6 \times 10^{7}-3 \times 10^{8}$ & $2.1 \times 10^{5}$ & $2 \times 10^{5}$ & $6 \times 10^{2}-4 \times 10^{5}$ & $0.001^{*}$ \\
\hline $2 \% \mathrm{CHX}$ & $4.8 \times 10^{7}$ & $5 \times 10^{7}$ & $1 \times 10^{7}-1 \times 10^{8}$ & $2 \times 10^{4}$ & $2 \times 10^{4}$ & $1 \times 10^{4}-9 \times 10^{4}$ & $0.001^{*}$ \\
\hline Gaseous $\mathrm{O}_{3}+\mathrm{O}_{3}$ water & $6.68 \times 10^{7}$ & $3 \times 10^{7}$ & $4 \times 10^{4}-4 \times 10^{8}$ & $1.77 \times 10^{6}$ & $1 \times 10^{6}$ & $1 \times 10^{3}-9 \times 10^{6}$ & $0.001^{*}$ \\
\hline Gaseous $\mathrm{O}_{3}$ & $2.38 \times 10^{6}$ & $2 \times 10^{7}$ & $3 \times 10^{5}-8 \times 10^{6}$ & $2.2 \times 10^{5}$ & $2 \times 10^{5}$ & $0.01-1 \times 10^{6}$ & $0.001^{*}$ \\
\hline Saline & $1.49 \times 10^{6}$ & $1 \times 10^{6}$ & $1 \times 10^{5}-3 \times 10^{6}$ & $1.49 \times 10^{6}$ & $1 \times 10^{6}$ & $0.1 \times 10^{6}-3 \times 10^{6}$ & 1.000 \\
\hline
\end{tabular}

Wilcoxon singned ranks test ${ }^{*} \mathrm{p}<0.01$.

which was placed $2 \mathrm{~mm}$ short of the working length.

Group 2, CHX group: The root canals were irrigated with $2 \mathrm{ml} 2 \% \mathrm{CHX}$ (Cerkamed, Poland) for 3 min using $30-\mathrm{G}$ needle, which was placed $2 \mathrm{~mm}$ short of the working length.

Group 3, Ozone group: Gaseous ozone was applied with an ozone-generating device (Ozonytron XP, MIO International Ozonytron $\mathrm{GmbH}$ Co., Germany) to deliver ozone in air at the rate of $44 \mathrm{mg} \mathrm{ml}^{-1}$ at $1 \mathrm{~atm} 20^{\circ} \mathrm{C}$ through the KPX probe for $3 \mathrm{~min}$.

Group 4, Gaseous ozone + ozonated water group: Gaseous ozone (as applied in group 3) and ozonated water ( $2 \mathrm{ml}, 3 \mathrm{~min}$ ) were used together subsequently. Ozonated water $\left(5 \mathrm{\mu g} \mathrm{ml}^{-1}\right)$ was freshly prepared using an ozone gas generator machine (Ozomed Basic) (Kastner-Praxisbedarf GmbH Co, Ltd).

Group 5, Saline (positive control) group: The contaminated root canals were irrigated with $2 \mathrm{ml}$ of $0.9 \%$ sterile saline solution.

Five samples received no treatment as negative control. The positive control was used to check bacterial viability and the negative control was used to test sterility throughout the experiment.

After carrying out the disinfection protocols, the root canals were irrigated with sterile saline $(2 \mathrm{ml})$ for $1 \mathrm{~min}$ and sampled by using 3 sterile paper points. Then the paper points were aseptically transferred to tubes containing $1 \mathrm{ml}$ of $\mathrm{BHI}$ broth and immediately homogenized using a vortex mixer at maximal setting for $30 \mathrm{~s}$. Following 10-fold serial dilutions, aliquots of $0.1 \mathrm{ml}$ were plated onto $\mathrm{BHI}$ medium agar in triplicate, incubated at $37^{\circ} \mathrm{C}$ aerobically for 48 hours and colonies were counted. The mean Colony forming units (CFUs) per unit determined for test cultures before and after treatment (mean $\pm S D ; n=15$ ) procedures for each experimental group were calculated and within the group.

Analyses were performed using IBM SPSS Statistics 22 (IBM SPSS, Türkiye). Kolmogorov-Smirnov test was applied to verify the distribution of the parameters between research groups. The resulting data were nonparametric and hence Kruskal-Wallis test was used to test for differences in bacterial reduction rate among groups and for intergroup comparative analysis. This global test was followed up with pair-wise comparisons
Table 2: Percentage reduction among groups.

\begin{tabular}{|l|l|l|}
\hline \% Reduction & $\begin{array}{l}\text { Median (Minimum- } \\
\text { Maximum/Range) }\end{array}$ & p \\
\hline $5.25 \% \mathrm{NaOCl}$ & $99.87(99.50-99.95)$ & \\
\hline $2 \% \mathrm{CHX}$ & $99.97(99.55-99.99)^{\ddagger}$ & \\
\hline Gaseous $\mathrm{O}_{3}+\mathrm{O}_{3}$ water & $95.00(86.67-99.75)^{\ddagger \neq}$ & $0.001^{*}$ \\
\hline Gaseous ozone & $90(70-98)^{\ddagger}$ & \\
\hline Saline & $0(0-0)^{\dagger}$ & \\
\hline
\end{tabular}

Kruskal wallis test ${ }^{*} p<0.01$, Mann whitney $U$ test $p<0.05$; ${ }^{\top}$ The group that showed less bacterial reduction percentage than the other tested groups $(p<0.05)$; ${ }^{\ddagger}$ The group that showed less bacterial reduction percentage than $\mathrm{CHX}$ group $(\mathrm{p}<0.05)$; ${ }^{\sharp} T$ he group that showed less bacterial reduction percentage than $\mathrm{NaOCl}$ group $(\mathrm{p}<0.05)$.

with Mann-Whitney U tests. Wilcoxon Signed Ranks test was used for the intragroup comparative analysis. The level of statistical significance was set at $\mathrm{P}<0.05$.

\section{Results}

Table 1 presents the distribution of the results (mean, median, range, reduction rate of CFUs) before and after disinfection protocols. The reduction in the number of CFUs after the treatment protocol was highly significant for all groups $(P<0.01)$ except saline group (positive control) $(p>0.05)$. All experimental groups were significantly superior over the positive control $(p$ : $0.001 ; p<0.01$ ).

Bacteria were viable in the positive control group, whilst the negative control group was free of microorganisms under the experimental conditions.

There was significantly different percentage reduction between the tested groups ( $p: 0.001 ; p<0.01$ ) (Table 2). The results showed that there was statistically a higher bacterial reduction in $\mathrm{NaOCl}$ group than gaseous ozone, gaseous ozone + ozonated water and $\mathrm{CHX}$ groups ( $p: 0.001 ; p<0.01$ ). The bacterial reduction percentage in $\mathrm{CHX}$ group (99.87\%) was significantly superior than in gaseous ozone group (90\%) and gaseous ozone + ozonated water group (95\%). Although combined disinfection with gaseous ozone and ozonated water group achieved higher bacterial reduction percentage than gaseous ozone group, there was no statistically significant difference among them ( $p: 0.076 ; p>0.05)$.

\section{Discussion}

According to the results of the present study, all experimental groups were successful in decreasing the bacterial count (except saline-positive control), 
while non of them was able to eliminate $E$. faecalis completely. This result may be due to the type of organism which is the most resistant phase to medication. Also, E. faecalis that found in the starvation phase produce intracellularly organic products, which may play a role in the inactivation of the antibacterial activity of the medicament [4]. Moreover, E. faecalis was chosen as the test organism in this study because it is the most often associated with persistent endodontic infections [5] and can be seen in primary endodontic infections [26]. Null hypothesis was rejected as there was difference in the antibacterial efficacy of gaseous ozone, gaseous ozone + ozonated water, $\mathrm{CHX}$, and $5.25 \% \mathrm{NaOCl}$. The percentages of bacterial reduction of the experimental groups were $90 \%, 95 \%, 99.87 \%$ and $99.97 \%$, respectively. The current results showed that $5.25 \% \mathrm{NaOCl}$ achieved the best antibacterial results among the tested groups. Consistent with our findings, Noites, et al. [12] reported that $\mathrm{NaOCl}, \mathrm{CHX}$ and gaseous ozone alone were ineffective in totally eliminating Candida albicans and Enterococcus faecalis.

They also stated that the association of $\mathrm{CHX}$ at $2 \%$ followed by ozone gas for 24 seconds promoted the elimination of all microorganisms. Huth, et al. [27] found that ozonated water and gaseous ozone eliminated over $96 \%$ of $E$. faecalis in biofilm when used in maximum concentrations (20 $\mathrm{g} \mathrm{m} \mathrm{m}^{-1}$ and $53 \mathrm{gm}^{-1}$, respectively), whereas lower concentrations reduced substantially but did not eradicated them.

Contrary to our results, Abdullah, et al. [28] concluded that $3 \% \mathrm{NaOCl}$ achieved $100 \%$ kill for all presentations of $E$. faecalis after a 2 min contact time. In our study, Total elimination of $E$. faecalis could not be achieved even with higher concentration of $\mathrm{NaOCl}$ (5.25\%) after 3 min contact. Within the methodology of the present study, we tested the efficacy of gaseous ozone plus ozonated water with the aim of providing to reduce $E$. faecalis biofilm in vitro. Based on the results of our study, ozonated water did not increase the antibacterial effect of gaseous ozone. Furthermore, gaseous ozone + ozonated water combination showed significantly less antimicrobial effect when compared with $\mathrm{NaOCl}$ and $\mathrm{CHX}$. Nagayoshi, et al. [21] reported that the ozonated water had the same activity with $2.5 \%$ $\mathrm{NaOCl}$ especially, in specimens irrigated with sonication in an in vitro study. The differences between the results of the mentioned studies and our results may be due to differences on the methodological design of each investigation: Standardization of tooth type and sample size, number of bacteria, incubation time, bacterial invasion of root dentinal tubules, quality control of the chemical irrigants and variation in their concentration. On the other hand, the irrigant concentration, contact time and the study model notwithstanding, the results of the present investigation are in accordance with those of previous studies $[29,30]$.
It is well known that $\mathrm{NaOCl}$ and $\mathrm{CHX}$ are most common antimicrobial agents used in the treatment of endodontic and periodontal infections $[1,28]$. In the study of Gomes, et al. [1], in vitro effectiveness of several concentrations of $\mathrm{NaOCl}(0.5 \%, 1 \%, 2.5 \%, 4 \%$ and $5.25 \%)$ and two forms of $\mathrm{CHX}$ in three concentrations $(0.2 \%, 1 \%$ and $2 \%$ ) in the elimination of E. faecalis were assessed. It was shown that all irrigants were effective in killing the bacteria tested. Similarly, we found that $5.25 \%$ $\mathrm{NaOCl}$ and $2 \% \mathrm{CHX}$ were effective in reducing $E$. faecalis. $5.25 \% \mathrm{NaOCl}$ showed superior antimicrobial effect than $\mathrm{CHX}$, whereas $\mathrm{CHX}$ showed better antibacterial effect compared with gaseous ozone, ozonated water and gaseous ozone + ozonated water in our study. Boch, et al. [31] reported that reduction of $E$. faecalis inside the root canals with gaseous ozone (2100 ppm-60 sn) was $85 \%$, while it was $90 \%$, in our study. The reason of the difference with the study of Botch, et al. [31]. Might be the longer application time of ozone gas ( $3 \mathrm{~min}$ ) despite less concentration of ozone that we applied. Using different ozone-generating devices also might have been caused the different results. We used Ozonytron XP (Ozonytron XP, MIO International Ozonytron GmbH Co., Germany) while they used HealOzone ${ }^{\circledR} 2130$ C (Kavo, Biberach, Germany) for endodontic disinfection.

Ozonated water and gaseous ozone were evaluated and compared with traditional endodontic irrigants as alternative disinfectants. It was recently shown that even in large root canals the efficacy of instrumentation is surprisingly low [32]. Moreover, a lot of other areas cannot be reached with instrumentation such as interconnecting canals. Thus, we focused on the antimicrobial effect of only disinfecting agents. As a source of impreciseness in the present study, no neutralizers were used to arrest the action of the agents. Thus, the contact times for irrigants, which are known for their substantivity might be prolonged similar as in the clinical situation.

There is still no consensus respecting the application manner, dosages and time of $\mathrm{O}_{3}$ to achieve significant results. Hems, et al. [29] reported that ozone had significant bacterial reduction but only applied for 240 s. However, Estrela, et al. [33] found that both ozonated water and gaseous ozone over 20 min was not sufficient to inactivate of $E$. faecalis. In the current study, the concentration of ozone gas and ozonated water were chosen according to manufacturer instructions. We were tested different time periods in a pilot study but no significant difference was achieved, thus so we decided to choose the application time as 3 minutes. We thought the time should be proper long for clinical use. It may be more effective if higher concentrations could be used with the ozone machines we have used. To the best of our knowledge, this is the first study investigating the antibacterial effectiveness of gaseous ozone $\left(44 \mu \mathrm{g} \mathrm{ml}^{-1}\right)$ and ozonated water $\left(5 \mathrm{\mu g} \mathrm{ml}^{-1}\right)$ with the indicated concentration and time ( $3 \mathrm{~min})$. 
Limitation of this study was to use only culture method by assessing the reduction in bacterial count. Biomolculer methods as realtime PCR or FISH (Rrna $16 \mathrm{~s})$ techniques could be used to determine bacterial reduction. It is stated that these techniques are more sensitive than culture technique in several recent studies [34,35].

\section{Conclusion}

Under the tested conditions and within the limitations of this study, it may be concluded that $\mathrm{NaOCl}$ is still the most efficient disinfection agent in terms of eliminating endodontic pathogens. The results of the current study could guide to redirect researches towards new protocols and disinfection agents for reducing bacteria in infected root canals. Gaseous ozone might be used as an adjunctive agent but not an alternative to $\mathrm{NaOCl}$. Although $E$. faecalis is the major pathogen in secondary endodontic infections, further studies should be carried out to investigate the treatment protocol of ozone for endodontic infections in different clinical situations and on different bacterial species.

\section{Acknowledgments}

Research was done at Marmara University dental school microbiology laboratory and all expenses met by us.

\section{References}

1. Gomes BP, Ferraz CC, Vianna ME, Berber VB, Teixeira $F B$, et al. (2001) In vitro antimicrobial activity of several concentrations of sodium hypochlorite and chlorhexidine gluconate in the elimination of Enterococcus faecalis. Int Endod J 34: 424-428.

2. Sundqvist G (1992) Ecology of the root canal flora. J Endod 18: $427-430$.

3. Peters LB (2005) Disinfection of the root canal system during endodontic treatment. Ned Tijdschr Tandheelkd 112: 467-470.

4. Portenier I, Waltimo T, Ørstavik D, Haapasalo M (2005) The susceptibility of starved, stationary phase, and growing cells of enterococcus faecalis to endodontic medicaments. J Endod 31: 380-386.

5. Sundqvist G, Figdor D, Persson S, Sjögren U (1998) Microbiologic analysis of teeth with failed endodontic treatment and the outcome of conservative re-treatment. Oral Surg Oral Med Oral Pathol Oral Radiol Endod 85: 86-93.

6. Wang Z, Shen Y, Haapasalo M (2012) Effectiveness of endodontic disinfecting solutions against young and old enterococcus faecalis biofilms in dentin canals. J Endod 38: 1376-1379.

7. Peciuliene V, Maneliene R, Balcikonyte E, Drukteinis S, Rutkunas V (2008) Microorganisms in root canal infections: A review. Stomatologija 10: 4-9.

8. Bystrom A, Claesson R, Sundqvist G (1985) The antibacterial effect of camphorated paramonochlorophenol, camphorated phenol and calcium hydroxide in the treatment of infected root canals. Endod Dent Traumatol 1: 170-175.

9. Mohammadi Z (2008) Sodium hypochlorite in endodontics: An update review. Int Dent J 58: 329-341.
10. Spencer HR, Ike V, Brennan PA (2007) Review: The use of sodium hypochlorite in endodontics-potential complications and their management. Br Dent J 202: 555-559.

11. Zamany A, Safavi K, Spangberg LS (2003) The effect of chlorhexidine as an endodontic disinfectant. Oral Surg Oral Med Oral Pathol Oral Radiol Endod 96: 578-581.

12. Noites R, Pina-Vaz C, Rocha R, Carvalho MF, Gonçalves $A$, et al. (2014) Synergistic antimicrobial action of chlorhexidine and ozone in endodontic treatment. Bio Med Res Int 2014: 1-6.

13. Huth KC, Jakob FM, Saugel B, Cappello C, Paschos E, et al. (2006) Effect of ozone on oral cells compared with established antimicrobials. Eur J Oral Sci 114: 435-440.

14. Peters LB, van Winkelhoff AJ, Buijs JF, Wesselink PR (2002) Effects of instrumentation, irrigation and dressing with calcium hydroxide on infection in pulp less teeth with periapical bone lesions. Int Endod J 35: 13-21.

15. Restaino L, Frampton EW, Hemphill JB, Palnikar P (1995) Efficacy of ozonated water against various food-related microorganisms. Appl Environ Microbiol 61: 3471-3475.

16. Reddy AS, Reddy N, Dinapadu S, Reddy M, Pasari S (2013) Role of ozone therapy in minimal intervention dentistry and endodontics-a review. J Int Oral Health 5: 102-108.

17. Sawadaishi K, Miura K, Ohtsuka E, Ueda T, Ishizaki K, et al. (1985) Ozonolysis of supercoiled pBR322 DNA resulting in strand scission to open circular DNA. Nucleic Acids Res 13: 7183-7194.

18. Estrela C, Estrela CR, Decurcio D de A, Silva JA, Bammann LL (2006) Antimicrobial potential of ozone in an ultrasonic cleaning system against staphylococcus aureus. Braz Dent J 17: 134-138.

19. Almaz ME, Sönmez IŞ (2015) Ozone therapy in the management and prevention of caries. J Formos Med Assoc 114: 3-11.

20. Kist S, Kollmuss M, Jung J, Schubert S, Hickel R, et al. (2017) Comparison of ozone gas and sodium hypochlorite/ chlorhexidine two-visit disinfection protocols in treating apical periodontitis: A randomized controlled clinical trial. Clin Oral Investig 21: 995-1005.

21. Nagayoshi M, Kitamura C, Fukuizumi T, Nishihara T, Terashita M (2004) Antimicrobial effect of ozonated water on bacteria invading dentinal tubules. J Endod 30: 778-781.

22. Meire MA, De Prijck K, Coenye T, Nelis HJ, De Moor RJ (2009) Effectiveness of different laser systems to kill enterococcus faecalis in aqueous suspension and in an infected tooth model. Int Endod J 42: 351-359.

23. Beer F, Buchmair A, Wernisch J, Georgopoulos A, Moritz A (2012) Comparison of two diode lasers on bactericidity in root canals-an in vitro study. Lasers Med Sci 27: 361-364.

24. Balić M, Lucić R, Mehadžić K, Bago I, Anić I, et al. (2016) The efficacy of photon-initiated photoacoustic streaming and sonic-activated irrigation combined with QMiX solution or sodium hypochlorite against intracanal E. Faecalis biofilm. Lasers Med Sci 31: 335-342.

25. Bitter K, Vlassakidis A, Niepel M, Hoedke D, SchulzeJ, et al. (2017) Effects of diode laser, gaseous ozone, and medical dressings on enterococcus faecalis biofilms in the root canal ex vivo. Bio Med Res Int 2017: 1-9.

26. Stuart CH, Schwartz SA, Beeson TJ, Owatz CB (2006) Enterococcus faecalis: Its role in root canal treatment failure and current concepts in retreatment. J Endod 32: 93-98. 
27. Huth KC, Quirling M, Maier S, Kamereck K, Alkhayer M, et al. (2009) Effectiveness of ozone against endodonto pathogenic microorganisms in a root canal biofilm model. Int Endod J 42: 3-13.

28. Abdullah M, Ng YL, Gulabivala K, Moles DR, Spratt DA (2005) Susceptibilties of two enterococcus faecalis phenotypes to root canal medications. J Endod 31: 30-36.

29. Hems RS, Gulabivala K, Ng YL, Ready D, Spratt DA (2005) An in vitro evaluation of the ability of ozone to kill a strain of enterococcus faecalis. Int Endod J 38: 22-29.

30. Buck RA, Eleazer PD, Staat RH, Scheetz JP (2001) Effectiveness of three endodontic irrigants at various tubular depths in human dentin. J Endod 27: 206-208.

31. Boch T, Tennert C, Vach K, Al-Ahmad A, Hellwig E, et al. (2016) Effect of gaseous ozone on enterococcus faecalis biofilm-an in vitro study. Clin Oral Invest 20: 1733-1739.
32. Markvart M, Darvann TA, Larsen P, Dalstra M, Kreiborg S, et al. (2012) Micro-CT analyses of apical enlargement and molar root canal complexity. Int Endod J 45: 273-281.

33. Estrela C, Estrela CR, Decurcio DA, Hollanda AC, Silva JA (2007) Antimicrobial efficacy of ozonated water, gaseous ozone, sodium hypochlorite and chlorhexidine in infected human root canals. Int Endod J 40: 85-93.

34. Siqueira JF Jr, Rôças IN (2003) PCR methodology as a valuable tool for identification of endodontic pathogens. $J$ Dent 31: 333-339.

35. de Oliveira BP, Aguiar CM, Câmara AC, de Albuquerque MM, Correia AC, et al. (2015) The efficacy of photodynamic therapy and sodium hypochlorite in root canal disinfection by a single-file instrumentation technique. Photodiagnosis Photodyn Ther 12: 436-443. 